\title{
Corporate governance in the Hungarian banking and insurance sector ${ }^{*}$
}

\author{
Ádám Angyal, Júlia Csanda ${ }^{* *}$
}

The financial sector has been one of the most profitable sectors of the Hungarian economy for years. The same financial sector which, in the nineties, underwent a painful and very expensive consolidation period. This matter of fact has drawn the researchers' attention to that particular sector. Is this the result, or at least partly, of outstanding corporate governance structures and practices? Making use of the questionnaire developed by the University of Chemnitz, the researchers wanted to get a detailed picture about the Hungarian financial sector's corporate governance structures and its approach of the corporate governance topic. Corporate governance is not the greatest preoccupation of the Hungarian financial institutions, their outstanding financial results are not due to outstanding governance structures, and they broadly have a legal approach of this topic.

Der Finanzsektor ist seit Jahren einer der profitabelsten Sektoren in der ungarischen Wirtschaft. Der gleiche Finanzsektor, der in den 90er Jahren eine schmerzhafte und sehr aufwändige Konsolidierungsphase hatte. Diese Tatsache hat die Aufmerksamkeit der Forscher auf diesen besonderen Sektor auf sich gezogen. Ist dies das Ergebnis oder zumindest teilweise, von außergewöhnlichen Corporate Governance Strukturen und Praktiken? Ausgehend von einem Fragebogen, der an der TU Chemnitz ausgearbeitet worden ist, wollten die Forscher ein detailliertes Bild über die Corporate Governance Strukturen des ungarischen Finanzsektors erhalten sowie über dessen Herangehensweise and die Corporate Governance Thematik. Corporate Governance hat nicht die höchste Priorität bei den ungarischen Finanzinstitutionen, ihre außergewöhnlichen finanziellen Ergebnisse haben sie nicht aufgrund von außergewöhnlichen Governance Strukturen, und allgemein haben sie eine rechtliche Herangehensweise auf diese Thematik.

Keywords: Financial sector, Corporate Governance, Hungary, banking, insurance

* Manuscript received: 01. 04. 06, acceptet: 03. 05. 06(0 revision)

** Ádám Angyal, Professor, Corviuus University Budapest. Corresponding address: adam.angyal@uni-corvinus.hu

Júlia Csanda, Research Assistant, Corviuus University Budapest. Main research areas: Business process, product management, adult training, strategic planning. 


\section{Introduction}

The field of corporate governance generally is concerned with the basic issue of instilling investors with the confidence that will permit them to hand over their money to managers. Over the past two decades, corporate governance has become a leading topic of discussion for researchers of finance, management, and law. Their goal is to find the optimal organizational arrangements to both protect shareholders' rights and at the same time increase economic efficiency.

Recent developments in corporate governance were mainly influenced by spectacular collapses in the United States and the United Kingdom caused by fraud, by mismanagement, or by the executives' pay and incentives. It is enough to mention the scandal linked to Barings Bank, one of the world's historic banks.

However, the situation of the Hungarian financial sector is extremely good: it has been one of most profitable sectors of the economy for years. The same Hungarian financial sector which, in the nineties, underwent a painful and very expensive consolidation period.

It is exactly the outstanding financial situation that draws the researcher's attention to that particular sector. Are these the result, or at least partly, of outstanding corporate governance structures and practices? Making use of the questionnaire developed by the University of Chemnitz, we wanted to get a detailed picture about the Hungarian financial sector's corporate governance structures and its approach of the corporate governance topic.

In our initial hypothesis, presently corporate governance is not the greatest preoccupation of Hungarian financial institutions, their outstanding financial results are not due to outstanding governance structures, and they broadly have a legal approach to this topic.

The rest of the paper is organized in the following way; the "State of the art" section provides general information about the corporate governance landscape in Hungary and the evolution of the Hungarian financial sector in the past few years.

The "Methodology" section describes the methodological background of the research. In the "Main Findings" we proceed to analyse and evaluate the answers given by the participants, in the order of the questionnaire. Finally, the "Conclusions" section assesses the results of the research and makes some points, which may be useful for future corporate governance research in the financial sector. 


\section{State of the art}

\subsection{Corporate governance in Hungary}

Hungary entered the corporate governance realm in 1990, following the political and social changes of 1989. Before that, less than 10 companies had been operating as share companies. All of them had been founded before the second world war and they could survive due to the fact that, among their owners, there were some companies from the victorious countries, especially from the U.S. Those 10 companies escaped the general nationalization wave between 19461948. Three of them still exist today: the Hungarian National Bank, the IBUSZ (tourism) and the Richter Gedeon (pharmaceutical industry).

In 1988, 90 percent of the total industrial and service output were produced by 2,000 state-owned companies. 80 percent of the agricultural output were produced by production cooperatives (kind of kolkhoz [I suggest inserting a brief definition for the non-specialist]) and 10 percent by state farms (kind of sovkhoz [ditto]).

The Parliament approved a new Company Act in 1988, which replaced the commercial acts of, respectively, 1875 and 1932. The new regulation, which has reflected mainly German legal principles, was thoroughly revised and amended twice: first in 1997 and then in 2006. EU recommendations regarding corporate governance have been built in the present version of the Company Act.

Since 1989 a great number of companies have been founded. Some of the former state-owned companies were reorganized as business firms, and some of them were split up to several smaller firms. Besides the Hungarian-owned companies, a great number of international companies have appeared due to the privatization or the greenfield establishment.

In 2004 there were 806,000 registered companies in Hungary (the population totals 10 millions). Approximately half of them actually pursue business activities. Overall 161,000 registered companies dispose of some kind of governance institution. Yet standard corporate governance functions can be identified only in the case of the 5,400 share companies. The economic importance of these companies is very high because they overall produce more than 50 percent of the GDP. The share [share holder? Or companies with shareholders?]companies exhibit the following governance characteristics:

1. Multinationals prefer to establish a subsidiary in the form of limited company because there's no need to set up a board of directors and, in many cases, not even a supervisory board.

2. Hungarian stock exchange handles but a little percentage of the total market capitalization with no more than 40 listed companies of category A. Notwithstanding, some of the Hungarian top companies (from the oil industry or the telecom sector) are actually listed on the stock exchange. 
3. Foreign investment is very important in the Hungarian economy. So far USD 50,000 millions have arrived, half of which are foreign direct investment.

4. Dominant financial groups are not likely to invest or to acquire companies in the Hungarian capital market, except for a few sectors (e.g. food industry, public utilities) where such trends have already appeared. Concentration of capital has also started, a great number of holding and related companies have appeared. In this latter case, headquarters intervene vigorously and direct the governance mechanisms, especially through the boards.

Overall, the legal and the economic environments of the corporate governance in Hungary meet the relevant international standards. The Budapest Stock Exchange has issued its corporate governance recommendations regarding the general assembly, the board of directors and the supervisory board.

\subsection{The evolution of the Hungarian financial sector}

The restructuring the financial systems in Central and Eastern European countries of transition to meet the requirements of a market economy has been a unique challenge of the past decade. Market-oriented reforms and bank restructuring are closely linked, since the success of the transition from a centrally managed economy dominated by state ownership to a market economy based on private ownership greatly depends on the stability of the financial system.

Hungary was the first Central European country to embark upon a reform of its banking system. Prior to the reform, Hungary had a monobank system with the Hungarian National Bank (HNB) performing both central banking and commercial banking functions. The first step of the reform was to separate the two functions of the HNB. A two-tier banking system was established in 1987 with the creation of three state-owned banks, which took over most of the commercial functions of the HNB.

The creation of the two-tier system left the ownership structure untouched: the newly founded banks remained state-owned. This led to corporate governance deficiencies. Many of the people delegated by the state to the banks' boards were either people to whom the state wanted to make a favor, or civil servants who were delegated there in order to supplement their weak income. Banks had to struggle with the inheritance of bad loan portfolios from earlier times when credit had been centrally directed, the sharp fall of the aggregate demand and output, and the large administrative costs. It became evident by 1992 that the sector was in a crisis and a consolidation and restructuring of the banking system could be no longer postponed.

The consolidation started in late 1992 and proceeded in three stages: portfolio cleaning, enterprise-oriented portfolio-cleaning and recapitalization. 
The government considered the privatization of the state-owned banks as the final step in strengthening and stabilizing the banking sector. It was concluded that the banks should preferably be sold to strategic owners who can provide capital, technology and know-how. In practice, this meant selling most of the state-owned banks to foreign private banks. As a result of the privatization and the greenfield establishment of foreign banks, the second half of the nineties witnessed a dramatic change in the ownership structure of the banking sector. Now 70 percent of the Hungarian banking system and 80 percent of the insurance sector are in the hands of foreign investors, while a good part of other subsectors, such as investment firms and pension funds, belong to these foreign banks and insurers as members of financial groups. State ownership still plays a role in the financial sector, however, this is not at all unparalleled [do you mean unusual?]in the OECD countries.

The reform of the insurance sector started in 1986 when a new insurer, called Hungária Biztosító, was separated from the state-owned Állami Biztosító. As a result of the privatization of these two insurers, the greenfield establishment of foreign insurance companies and the adoption of a specific industry law, a regulated insurance market was established by the middle of the nineties.

Now we will briefy examine the profitability figures:

The profitability of the Hungarian banking sector is very high in terms of return on equity (ROE): in 2005 the average ROE was 22.6 percent, in 2003 it was 18 percent, while the banking sector of the EU-15 countries produced an average ROE of 10 percent in 2003. The profit before tax of the Hungarian banking sector totalized HUF 320,000 millions in 2005 , which represents a 20 percent increase compared to the 2004 figures.

The average ROE of the Hungarian insurance sector was 24.3 percent in 2002, highly above the EU average. The profit before tax totalized HUF 63,000 millions in 2005, which represents a 56 percent increase compared to the 2004 figures.

\section{Methodology of research}

The research took place between 1-07-2005 and 31-08-2005 in the Hungarian banking and insurance sector. The authors made use of the "Corporate Governance Questionnaire" developed by the University of Chemnitz. However a certain amount of modification had to be made to it so that Hungarian companies could interpret the questionnaire properly. Namely, the original questionnaire made reference to the German-type supervisory board, which is different from the Hungarian two-tier system. In Hungary, the executive board and the supervisory board are two different legal constructs, and there's no subordination between them. Therefore an additional section - Executive Board was inserted next to Supervisory Board section with identical questions. 
The structure of the questionnaire is as follows:

1. General Questions

2. Ownership

3. Top Management

4. Supervisory Board

5. Executive Board

6. Stakeholders

The questionnaire was sent by e-mail to the institutions. From the 11 credit institutions and 7 insurance companies requested, respectively 5 and 2 returned the questionnaire, so the rate of return is nearly 40 percent.

To simplify things, in this paper we frequently use the term financial sector and financial institutions to describe the target group of our research. It must be noted, however, that the financial sector comprises not only the „banking and insurance" category, originally included in the questionnaire, but a number of legally different subsectors as well, such as investment firms, pension funds, etc. The research has not been extended to these subsectors.

In the following sections we will have to make references to the respective industry laws, since each of them implies corporate governance rules in addition to the general regulations of the Company Act. The Act about Credit Institutions and Financial Undertakings will be shortened „ACIFU”, and the Act about Insurers and Insurance Activities will be shortened „AIIA”.

\section{Main findings}

\subsection{General questions}

The participants are credit institutions or insurance companies. Most of the institutions were established during the period of the political changes, following the market liberalizations in the late 1980s. There are two exceptions. The first is an institution established in 1950, which must have been established and directed for a long time by the Hungarian state [? What type of institution is it?, is this the Security fund?]. The second is a savings' co-operative established in 1970, which could operate in its present co-operative form at that time but it was not authorized to open branches in the cities and grant loans until the end of the 1980s.

The institutions are important employers, except for the savings' co-operative. While the big commercial banks operate a nationwide network, the savings' cooperative has its branches only in one or two small regions.

As to the A4 question (,What was the turnover of your company last year?") the banks aspired to give their balance sheet figures instead of the turnover. The insurance companies gave figures representing the total of the transactions 
covered by insurance. It means that the financial sector understands and uses figures other than the traditional turnover figures.

5 from the 7 institutions gave account of an increase - what is more: a rapid increase in 3 cases - of their turnover during the past 5 years.

6 from the 7 institutions are not registered on the stock exchange, and the seventh did not give information about it (but it is known that the seventh institution is not registered). The Hungarian banking and insurance industry is not characterized by an intense participation on the stock exchange. Most of the Hungarian banks and insurance companies were privatized or established as a subsidiary by foreign financial institutions. However, as the foreign owners are registered on their respective stock exchanges, we can draw the conclusion that their Hungarian subsidiaries indirectly comply with the requirements of the stock exchange on which the mother company is registered.

\subsection{Ownership}

4 of the 7 institutions researched are owned by foreign financial institutions. There is a bank which is owned 100 percent by the Hungarian state, and there is an insurance company which is owned 75 percent by domestic financial institutions and 25 percent by the Hungarian state. These two institutions are not traditional commercial banks or insurance companies, they exercise activities specified by the Hungarian state. The third exception from the foreign ownership is the savings' co-operative which is 97.5 percent owned by the (domestic) Security fund of savings' co-operatives. 4 from the 7 institutions requested are part of an international group as a subsidiary. None of the institutions perceive itself to be a family firm.

\subsection{Top management}

The institutions gave figures varying from 2 to 12 people. There are 2 top managers in the savings' co-operative and there are 12 top managers in the bank owned by the Hungarian State. Note that the ACIFU prescribes a minimum of two managing directors for the credit institutions, so it is supposed that our institutions meant the managing directors according to the ACIFU by the question concerning the top management.

In the banks owned by foreign institutions, the foreign managers are still present in the top management. The present CEO has held his position for more than 10 years in 4 institutions, what is more: the savings' co-operative gives the information that his chairman-managing director has held his position for 22 years. As to the state-owned institutions, changes in the government determine the changes in the CEO's person. Most of the institutions do not remunerate their top managers with stock options. This fact may be brought into connection with the principle of prudential operation of banks. 
The institutions published in 2004, respectively, $0,2,10,20,60,100$ ad hoc public messages. They probably did not all understand well what was meant by „ad hoc public messages" in the questionnaire. Financial institutions have the mandatory obligation to publish every little modification of their terms and conditions, therefore it is impossible to imagine a bank not publishing anything during the year.

Only 2 from the 7 institutions have a department dealing with investor relations. It must be noted, however, that the term ,investor relations" is ambiguous when applied to financial institutions, since loans are often placed to serve investment purposes.

The external auditor is regularly exchanged only by 2 from the 7 institutions. The top managers always attend meetings of the board, which might be explained by the fact that themselves are members of the board.

\subsection{The Supervisory board}

While the Company Act determines that 3 people is the minimum number and 15 people the maximum number of people who can serve as supervisory board members, the ACIFU limits the maximum number in 9 people in the case of credit institutions. In our research, there is an insurance company with 3 members, and there is a state-owned bank with the maximal 9 members, the same bank which has 12 top managers.

In the supervisory board of the foreign-owned banks foreign members outnumber the Hungarian members. 5 from the 7 institutions have supervisory board members elected by the employees. In 6 from the 7 institutions' supervisory board male members outnumber largely the female members.

Both the Company Act and the ACIFU preclude from the supervisory board people employed by the company - except for members elected by the employees. Therefore it is impossible for a CEO to become chairman or voting member of his/her company's supervisory board.

The composition of the foreign-owned banks' supervisory board is simple: there are the owner's representatives and the employees' representatives. The case of the savings' co-operative is unique and exceptional: the Security fund doesn't have a single representative on the supervisory board.

The state-owned bank reports that among the supervisory board members there is no one who represent firms [outside firms?] or people with major ownership in the firm. However, it is well known that members of the state-owned companies' supervisory board are nominated by the organization exercising the owner's rights and the latter will prefer those people who are committed to represent its interests. 
There are no supervisory board members who represent the other stakeholders in a broad sense, for instance the suppliers, the customers or the local communities' representatives. This fact may have to do with the undeveloped civilian society.

The supervisory boards held between 2 (a foreign-owned bank) and 14 (the state-owned bank) meetings in 2004. Only 3 foreign-owned banks report that their board took formal decisions outside the ordinary board meetings.

The question D9 inquires about the use of some modern corporate governance methods by the supervisory board. The ACIFU prescribes in detail the tasks of the financial institutions' supervisory board, one of the most important tasks being the direction of the company's internal audit system. This may partly explain the fact that 5 from the 7 institutions don't use any of those CG-methods, because their respective supervisory board concentrates on the legal requirements.

Board members are remunerated with a monthly or an annual basic fee, except for a bank which doesn't pay any remuneration to its board members. (The reliability of this information may be questioned since it is well known that membership in a financial institution's board is an important source of income.).

The D11 and D12 questions, inquiring about eventual conflicts between board members and the contribution made by the supervisory board, could not be answered without bias by the person who filled in the questionnaire. Overall, there aren't often conflicts or disagreements between board members, except for the foreign-owned insurance company. None of the institutions agree with the statement that the supervisory board replaces the top management (anyway, the legal requirements preclude this possibility). The largest contribution made by the supervisory board is that it controls business results and, in a smaller degree, it provides advice on different issues and it contributes to networking.

\subsection{The executive board}

This additionnally inserted section contained the same questions concerning the executive board as the previous chapter concerning the supervisory board.

The Company Act defines the executive board as the company's directing board. It can have a maximum of 11 and a minimum of 3 members. The trend is that executive boards are larger than supervisory boards. Foreign-owned institutions' executive board has at least one, but no more than 7 (from a total of 9) foreign members. The latter figure has to do with the ACIFU which prescribes at least 2 Hungarian members for the financial institutions' executive board. There aren't members elected by the employees in any executive board. In 4 from the 7 institutions there aren't any women in the board.

The internal members („CEO or other top executives in the firm”) outnumber the external members in 2 from the 7 institutions (both are foreign-owned banks). The ACIFU prescribes at least 2 internal members for the credit 
institutions and 1 internal member for the co-operative credit institutions. Furthermore, the ACIFU specifies the professional background necessary for the financial institutions' executive board members, which is checked by the Hungarian Financial Supervisory Authority prior to the election for board membership. It is to be noted that the Company Act leaves it to the companies' owners to elect the members with the professional background they want.

In the foreign-owned banks' executive board the internal members are the CEO or other top executives in the firm, and the external members are the CEO or other top executives of other companies, that is, the representatives of the owner firm.

There are only two institutions (the state-owned bank and the partly state-owned insurance company) which have external board members other than the owner's representatives. Nevertheless, it is known that the state is often represented by (politically influenced) agents instead of civil servants.

It is the composition of the savings' co-operative's executive board which is the most particular [unusual or peculiar?] in so far as it has no members delegated by the majority owner (the Security Fund of the savings' co-operatives). This may seem an extraordinary self-limitation, but the truth is that the Security Fund is not a real owner or investor. The Fund was established jointly by the Hungarian Ministry of Finance and more than two hundred savings' cooperatives in 1993, in order to stabilize those savings' co-operatives with financial difficulties. Capital assignment has been one of the stabilization tools used by the Security Fund. Furthermore, it controls its member organizations through its nationwide supervisory and preventive activities.

There are no members who represent the stakeholders of other institutions, just as in the the case of the supervisory board.

Each CEO is a voting member of the executive board. In 2 from the 7 institutions the CEO is the chairman of the executive board. The Executive boards hold more meetings (an average of 7.5 in 2004) than the supervisory boards (an average of 6.3 in 2004).

One of the foreign-owned banks does not make use of any of the 8 modern corporate governance tools listed in the E9 question. The other extreme is the state-owned bank which reports the use of 4 tools. There are 4 mentions of a CEO working description, 3 mentions of a regular top management evaluation and 3 mentions of written rules of board member remuneration.

The executive board members are remunerated with a monthly or an annual basic fee, except for a bank which pays a remuneration to the chairperson but not to the board members. (The reliability of this answer may be once again questioned. Foreign owners often remunerate their employees delegated to the subsidiaries' boards without informing the subsidiary of this.) 
The E11 and E12 questions could not be answered without bias by the person who filled in the questionnaire. There are not often conflicts or disagreements between board members. The reasons for this may be diverse: board members are accustomed to each other, good personal relations, the same attitudes to things - but the reason may as well be the fear of conflicts.

The three main contributions made by the executive board (in a decreasing order): contributes to networking, contributes to lobbying, provides advice on different issues.

\subsection{Stakeholders}

The average results of the F1 question - „how strong the company's corporate governance is influenced by the stakeholders" - are the following (from 1 ,,very strong”, to 4 ,non existing”:

1. State authorities: 2.1

2-3. External auditors / Banks: $2.3-2.3$

4. Broader society: 2.6

5. Customers: 2.8

6. Media: 3

7. Employees: 3.1

8-9. Suppliers / Unions: $3.5-3.5$

10. Local municipality: 3.8

It has been found that state authorities influence the strongest the financial institutions' corporate governance. As it was mentioned earlier, the respective industry laws imply corporate governance rules in addition to the general regulations of the Company Act, and the Hungarian Financial Supervisory Authority has got strong control rights over the supervised institutions. External auditors stand second together with banks. External auditors are also a sort of authority for the financial institutions, which results from the important part assigned to them by the industry law. The category of „banks” can have two meanings here: some of the institutions may have meant the owner bank by it, and some of them may have meant the competitor banks.

The middle third contains the following categories: broader society, media, customers, employees. It is interesting to see the customers in a relatively modest influencing role. This might be explained by the fact that the supervisory authority has the mandatory obligation to represent the interests of the financial institutions' customers, because those institutions trade with a special merchandise: the money of the customers (deposit holders). The weak influence of each small deposit holder has to be levelled up by the supervisory authority. The relatively weak influence of the employees makes us think since employees' representatives are sitting in the supervisory boardroom of most of the institutions. Isn't it not more than a formal compliance with a legal requirement? 
The bottom third contains the following categories: suppliers, unions, local municipality. The suppliers play a less important part in the financial institutions' operations than in the production or trade companies'. The weak influence of the unions characterizes not only the financial institutions but all sectors in Hungary. The local municipalities are placed last, which means that these institutions operate almost completely independently of the local communities.

As to the last question, 3 from the 7 institutions did not know about any official corporate governance code in Hungary; the others gave an answer in the affirmative. It means that 3 institutions did not hear of [perhaps insert: were apparently not aware of] the document entitled „Responsible Corporate Governance Recommendations", issued in 2004 by the Budapest Stock Exchange. By its contents, this document meets the requirements of an official corporate governance code. The average grades given by 4 institutions are the following (from 1 ,very good" to 4 ,very bad"):

a) Adaptability to your company's specific situation: 1.7

b) Adaptability to the branch of your company: 2.3

c) Relevance to the large shareholders of your company: 2

d) Relevance to the small shareholders of your company: 3.3

e) Relevance to the employees of your company: 1.7

f) Relevance to your company's relationship with banks: 2.5

g) Costs arising for your company to comply with this code: 2.2

h) General degree of fame: 1.7

i) Efficiency to improve corporate governance in our country: 2

\section{Conclusions}

Even if the seven returned questionnaires constitute not more than a segment of a sector with multiple actors, the main tendencies can be captured and made apparent, what is more, contents and research methods concerning this specific sector can be refined.

Our initial hypothesis has been proved: the Hungarian financial sector is characterized by a strong legal approach to corporate governance. This statement is even more emphasised by the fact that two of the requested institutions declined to fill in the questionnaire explaining that the answers to our questions can be found in the respective industry law. The legal approach is likely to strenghten further due to the coming implementation in the EU of the new capital adequacy framework, based on the Basel II rec The research has shown that modern corporate governance practices, such as the system of committees for example, are not used even by the largest executive boards. Yet a number of differences can be found, especially between the foreign private-owned institutions and the domestic state-owned institutions. State ownership seems to 
urge more the institutions to operate transparently than foreign private ownership. State-ownership has also been over-represented in our research: 3 from the 7 institutions (approximately 43 percent of the participants) are directly or indirectly owned by the Hungarian state, while they constitute a very moderate minority among the totality of banks and insurers.

It has to be added that the methodology used has its limits. Further to the addition of a new chapter on the executive board, mentioned in the methodology section of this paper, some of the questions couldn't be answered without bias by the person who filled in the questionnaire. Therefore it would be better to ask for those data in a personal interview. The interview gives the opportunity to obtain more precise data, as well as further background information. In future research, it is recommended to personalize the questions in order to take into account the special features of bank governance: the importance of risk management, the role of the supervisory authority, the problems arising from the information asymmetry, and the consequences for the owners and depositors stemming from a much higher level of gearing than in non-bank organizations.

We also intended to investigate the question to what extent financial institutions were preoccupied with corporate governance matters. Having done some theoretical and practical research, we can conclude that corporate governance is not very high on their agenda.

We have seen the very high profitability figures of the Hungarian banking and insurance sector in the second section of this paper. But one must be careful: it is not at all [clear whether these] outstanding results are due to an outstanding effectiveness, excellent governance structures and practices, and to a quality beyond EU average.

The high profitability of the domestic banking system is mainly due, according to the Hungarian Financial Supervisory Authority, to the big interest spread which, in turn, is more or less a direct consequence of the prevailing macroeconomic conditions. However, in the medium term the differences between Hungarian and EU interest structures, resulting from different inflation rates and government / central bank distortion, will disappear. For this reason, it would not come as a surprise if the ROE attainable in the domestic banking sector would fall to the level customary in the EU by the end of this decade, leading to harsher price competition.

Therefore Hungarian banks and insurers have to prepare themselves for a period when the decreasing profits and dividends will urge the shareholders to exercise more control over the company and to adopt the best international practices in every sphere of activity, inclusive of corporate governance.

In addition, banks and insurers have to prepare themselves to a tightening regulatory framework. Demand for increasing investment security is growing worldwide. This is achieved, according to the general opinion today, by 
tightening prudential regulation, gradually enforcing requirements concerning service providers' responsibilities for products, intensifying supervisory activities and by strengthening consumer protection.

\section{References:}

Shleifer, A./Vishny, R.: A Survey of Corporate Governance. in: Journal of Finance, 1997/522.

Hungarian Financial Supervisory Authority, Analytical and Methodology Directorate: The effect of EU accession on the Hungarian Financial Sector. May 2003, Budapest.

Pénzügyi Szervezetek Állami Felügyelete, Szabályozási, elemzési és nemzetközi Igazgatóság: Gyorsjelentés a pénzügyi szektor 2005. évi fejlődéséről. 2006. február, Budapest [translation into English?]

Basel Committee on Banking Supervision: Enhancing Corporate Governance for Banking Organisations. 1999, Basel

Szapáry, G.(2001): Banking Sector Reform in Hungary: Lessons Learned, Current Trends and Prospects. in: Hungarian National Bank Working Papers 2001/5, Budapest.

1996. évi CXII. Törvény a hitelintézetekről és pénzügyi vállalkozásokról

1997. évi CXLIV. Törvény a gazdasági társaságokról

2003. évi LX. Törvény a biztosítóintézetekröl és a biztosítási tevékenységrőla de 